\title{
The Impact of a Silane Pigment Treatment on the Properties of Thickness-sensitive Spectrally Selective Paints
}

\section{Miha Steinbücher, ${ }^{1}$ Peter Venturini, ${ }^{1}$ Jože Hafner, ${ }^{2}$ Matevž Zupančič, ${ }^{3}$ Peter Gregorčic ${ }^{3}$ and Iztok Golobicic ${ }^{3, \star}$}

\author{
${ }^{1}$ Helios Group, Količevo 2, SI-1230 Domžale, Slovenia \\ ${ }^{2}$ Slovenian National Building and Civil Engineering Institute, Dimičeva 12, SI-1000 Ljubljana, Slovenia \\ ${ }^{3}$ University of Ljubljana, Faculty of Mechanical Engineering, Aškerčeva 6, SI-1000 Ljubljana, Slovenia \\ * Corresponding author: E-mail: iztok.golobic@fs.uni-lj.si \\ phone: +38614771420
}

Received: 17-06-2017

\begin{abstract}
Thickness-sensitive, spectrally selective paints based on a silane treatment of pigments were prepared with different pigment-volume concentrations. The critical pigment-volume concentration was determined by means of electrochemical impedance spectroscopy, while the pigment particle size distribution was determined with ultrasound spectroscopy. The selectivity versus thickness relation of a paint with a near-critical pigment-volume concentration was studied spectroscopically through performance criteria. Its nonlinearity was shown to be related to the surface topography. This relation was further supported by hydrophobicity measurements. Heat-gathering tests in a simulated solar collector supported the spectroscopic determination of an optimal dry-film thickness.
\end{abstract}

Keywords: TSSS paints, pigment treatment, spectral selectivity, topography, hydrophobicity

\section{Introduction}

Spectrally selective paints play a crucial role in solar collector panels needed for efficient solar-thermal conversion systems. ${ }^{1}$ Such systems require spectrally selective absorbers with high absorption of the sunlight and low infrared emittance resulting in little heat lose to environment via convection and radiation. The established measure for the solar irradiation absorptivity as a material property is the solar absorptivity $\left(\alpha, a_{\mathrm{s}}, \alpha_{\mathrm{s}}\right)$, defined by the following equation:

$$
a_{S}=\frac{\int_{0.3 \mu m}^{2.5 \mu m} S(\lambda)(1-R(\lambda)) d \lambda}{\int_{0.3 \mu m}^{2.5 \mu m} S(\lambda) d \lambda}
$$

where $S(\lambda)$ is the normalized direct solar irradiation distribution function ${ }^{2}$ and $R(\lambda)$ is a hemispheric reflectance spectra of the material surface. On the other hand, the established measure of the fraction of black-body emissivity at a given temperature for a material is the thermal emissivity $\left(\varepsilon, \mathrm{e}_{\mathrm{T}}, \varepsilon_{\mathrm{T}}\right)$, defined by the following equation:

$$
e_{T}=\frac{\int_{2.5 \mu m}^{15 \mu m} r(\lambda, T)(1-R(\lambda)) d \lambda}{\int_{2.5 \mu m}^{15 \mu m} r(\lambda, T) d \lambda}
$$

where $r(\lambda, T)$ is the black-body radiation distribution function at a given absolute temperature $(T)$. Since high solar absorptivity and a low thermal emissivity are desired for solar-energy exploitation, the performance criterion $P C_{C}$ was introduced as a measure of the spectral selectivity, combining both $\mathrm{a}_{\mathrm{S}}$ and $\mathrm{e}_{\mathrm{T}}$ :

$$
P C_{C}=-a_{s}+C e_{T}
$$

where $C$ is a constant appropriate for the collector type used. The most commonly used values are $C=0.5$ for high-temperature collectors, $C=0.25$ for low-temperature collectors and $C=0.34$ for unglazed collectors. The $C$ values as well as classification of collectors are based on experimental work. ${ }^{3}$

Coatings, made from organic spectrally selective materials, ${ }^{4,5}$ represent one of efficient options to produce 
spectrally selective absorbers. They can be divided into thickness-insensitive, spectrally selective, ${ }^{6-10}$ and thickness-sensitive, spectrally selective (TSSS) paints. ${ }^{11}$ The development of both types is interlinked in the fields of absorptive pigments and their dispersions, ${ }^{12}$ binders, ${ }^{13}$ and durability. ${ }^{14,15}$ Typically, black TSSS coatings are based on an interaction between a thin layer of highly absorptive paint applied without a primer and a thermal infrared reflective substrate, such as aluminum, copper or other metals. Their selectivity depends to a large extent on their thickness, as both $a_{\mathrm{S}}$ and $\mathrm{e}_{\mathrm{T}}$ increase non-linearly with thickness. However, the thickness of the TSSS coatings is seldom measured, as their usual dry-film thicknesses is of the same magnitude as the surface roughness of the commonly used substrates, but thickness measurements commonly used in the paint industry cannot be reliable. ${ }^{16}$ The grammage, i.e., the weight of coating per nominal surface, roughness disregarded, is used instead. The other factor influencing selectivity is the substrate. However, its influence on $\mathrm{a}_{\mathrm{s}}$ is not significant with coatings applied in usual thicknesses $\left(a_{\mathrm{s}} \geq 0.9\right)$. On the other hand, $\mathrm{e}_{\mathrm{T}}$ is very (and almost linearly) dependent on the substrate $\mathrm{e}_{\mathrm{T}}$

Since the development of solar selective absorbers with both high conversion efficiency and high-temperature stability remains a challenging issue due to the cost and the materials problems, ${ }^{17}$ the main aim of this work is examination of the selectivity of in-situ silane-treated-pigment TSSS (stpTSSS) paints. Therefore, we are focused in study of performance criteria as a function of pigment concentration as well as on the optical properties of the pigment, the binder and the surface topology. Here, the surface-topography study is supported by hydrophobicity analysis performed through measurements of the static contact angle of a water droplet.

\section{Materials and Methods}

The stpTSSS paints were produced according to a previously disclosed procedure. ${ }^{4}$ The SUNCOLOR TS S Black $\mathrm{Al}$ (Helios Group, SI) paint was used for the particle size determination, topography studies, contact-angle measurements and tests of the heat-gathering properties. Solarect Z (Helios Group, SI) was used as a reference TSSS paint without silane-treated pigments. The paints were applied by spraying, bar or coil coating, diluted with the appropriate Helios SUNCOLOR Thinner (Helios Group, SI) or SUNCOLOR Thinner (Helios Group, SI). The substrates used were acid-pretreated, 0.2-mm-thick, copper $\left(\mathrm{e}_{\mathrm{T}}=\right.$ 0.03) sheets and degreased, 0.4-mm-thick aluminum sheets $\left(e_{T}=0.01-0.02\right)$. The coatings were cured in a calibrated Kambič LSP- $190 \mathrm{C}$ laboratory oven with $\pm 5^{\circ} \mathrm{C}$ precision at temperatures $>100^{\circ} \mathrm{C}$.

The coatings' grammage was determined by weighing the difference of uncoated and coated substrates with known surfaces. The masses were determined with a preci- sion of $\pm 0.0001 \mathrm{~g}$. The surfaces of the rectangular samples were determined by measuring their length and width with a precision of $\pm 0.5 \mathrm{~mm}$. The resulting grammage measurement error for a substrate of $10.0 \mathrm{~cm} \times 10.0 \mathrm{~cm}$, typically used in this work, is $0.01 \mathrm{~g} / \mathrm{m}^{2}$.

The $\mathrm{a}_{\mathrm{S}}$ values were determined by recording the UVVIS-NIR spectra with a Perkin Elmer Lambda 950 spectrometer with a $150-\mathrm{mm}$ Spectralon integration sphere and processing the spectral data according to equation (1). The error in the measurement of $\mathrm{a}_{\mathrm{s}}<<0.01 .^{18}$

The $\mathrm{e}_{\mathrm{T}}$ values were determined by recording the IR spectra with a Bruker IFS66/S spectrometer using an OPTO-SOL integration sphere and processing the spectral data according to equation (2). The error in the measurement is not documented.

The Electrochemical Impedance Spectroscopy (EIS) measurements were performed with a Parstat 2273 potentiostat and a Tait cell. The measuring system has a resolution of $1 \mathrm{pA}$. The EIS ${ }^{19}$ data were plotted as a Nyquist chart showing the imaginary impedance (Z") versus the real impedance $\left(Z^{\prime}\right)$. The higher arc shows a higher coating capacity and thus better barrier properties and a lower permeability. The EIS data were used for a critical pigment volume concentration (cPVC) determination of the coatings according to the previously described method. ${ }^{20,21}$

The particle sizes were determined with a Dispersion Technology DT-1200 acoustic spectrometer. The method based on acoustic attenuation versus an ultrasound frequency measurement allows for a particle size determination in a realistic, undiluted sample, which is in contrast to the more common dynamic light scattering. The particle size distribution is calculated from the recorded ultrasound spectrum, the dry-matter content, and densities using a unimodal or bimodal model. The uncertainty of the measurement for the sample relevant to this work is below $20 \mathrm{~nm}$.

The substrate and coating topographies were determined with an AFM Park XE100 atomic force microscope with a spatial resolution of $500 \mathrm{pm}$ and $150 \mathrm{pm}$ of background noise. The uncertainty of the measurement for the samples relevant to this work is below $1 \mathrm{~nm}$.

The static contact angles for water were measured with a Krüss DSA 100 drop shape analysis system with the error of the measurement being $<1^{\circ}$. Three measurements were made for each sample and then averaged.

The thermal response to irradiation was determined with stagnation-temperature measurements of a model absorber in a glazed or unglazed thermally insulated housing. The illumination was provided by filtered Atlas metal halide lamps; the power was regulated by changing the distance between the lamps and the absorber. The light flux was determined with a Kipp \& Zonen CM11 pyranometer with a spectral range of $285-2800 \mathrm{~nm}$ and a zero offset $<7$ $\mathrm{W} / \mathrm{m}^{2}$. The temperature was measured by means of type- $\mathrm{K}$ thermocouples, and a Agilent 34970A and a Windows PC were used for the data acquisition. Low-Fe-content glass with $\mathrm{T}=0.92$ was used for the glazing. 


\section{Results and Discussion}

\section{1. PVC Optimization}

Paints with different pigment volume concentrations (PVCs) were produced according to the already known procedure and applied to a copper substrate by air spraying. ${ }^{22}$ The silane coating of pigment in-situ during the dispersion process allows for a better dispersion and smaller particle size, as shown in Fig. 1.
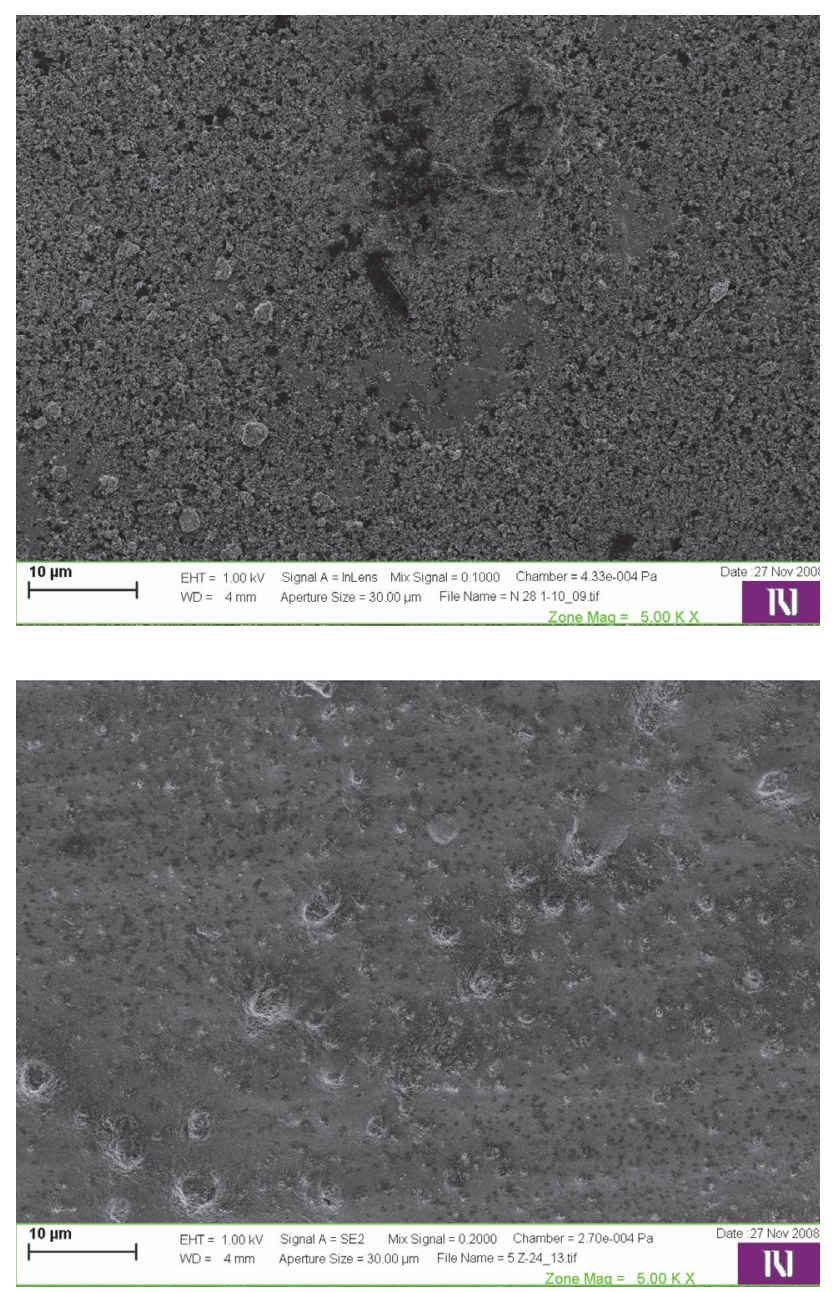

Figure 1. SEM analysis of surfaces of TSSS coatings made of silane treated (top) and untreated (bottom) pigments. Samples were made with the same PVC and the same application process.

The $\mathrm{a}_{\mathrm{S}}$ and $\mathrm{e}_{\mathrm{T}}$ values of the resulting coatings are shown in Figs. 2 and 3 with the $\mathrm{a}_{\mathrm{S}}$ and $\mathrm{e}_{\mathrm{T}}$ curves for the Solarect Z24 paint with PVC 27 as a reference. Both paints are based on the same binder and pigment and are formulated with the same PVC. The previously known relationship between the PVC and the spectral selectivity of a TSSS paint is also relevant for the stpTSSS paints. Paints with a higher PVC exhibit higher $\mathrm{a}_{\mathrm{S}}$ and lower $\mathrm{e}_{\mathrm{T}}$ for the same grammage and substrate.
The advantage of the new material is even clearer in a comparison of the $\mathrm{PC}$ values. Fig. 4 shows the $\mathrm{PC}_{0.5}$ values derived from the above data.

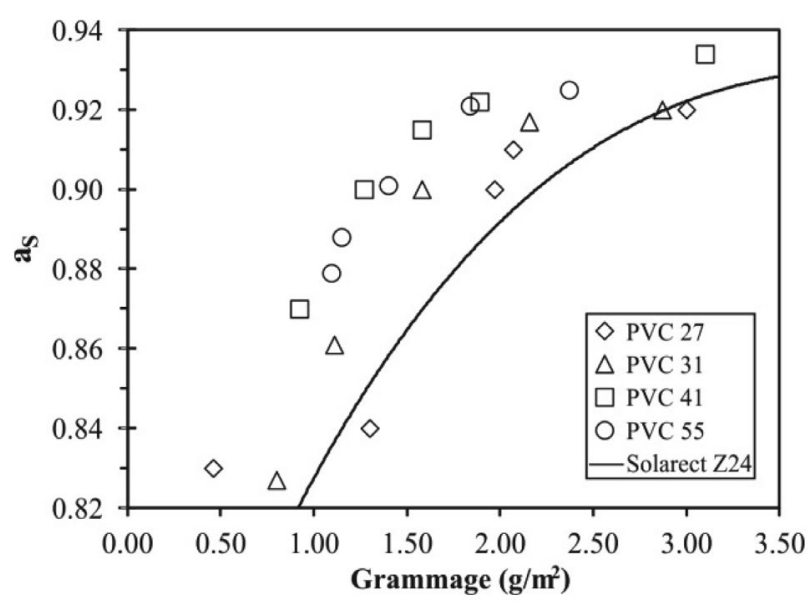

Figure 2. $\mathrm{a}_{\mathrm{s}}$ as a function of grammage for stpTSSS at different PVC with a non-silane treated reference, increase of PVC leads to higher $a_{\mathrm{s}}$ values.

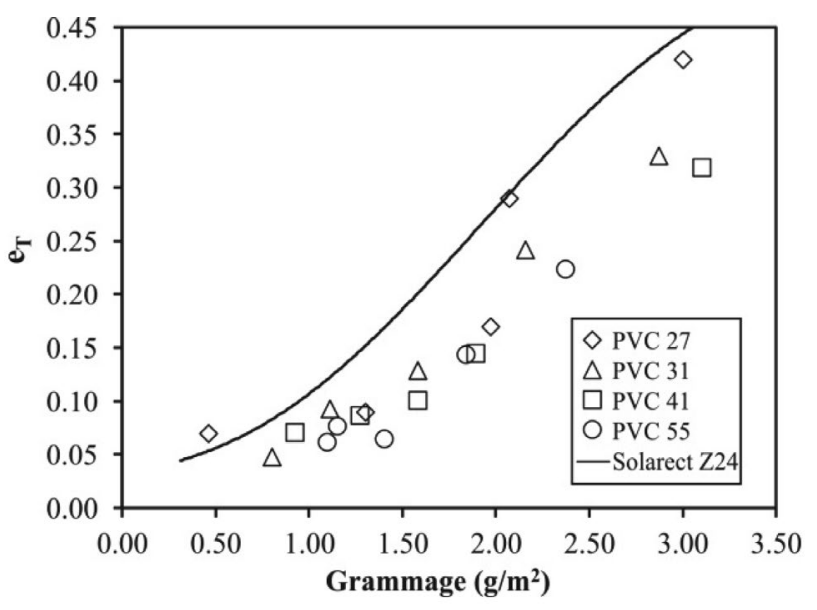

Figure 3. $e_{T}$ as a function of grammage for stpTSSS at different PVC with a non-silane treated reference, increase of PVC leads to lower $\mathrm{e}_{\mathrm{T}}$ values.

It is clear that the new coatings display better selectivity at a given PVC compared to the reference, but the silane-pigment-treating technology offers a further advance. The reference coating is limited to its PVC with the mechanical properties. The stpTSSS, on the other hand, can be produced at significantly higher PVCs without any apparent loss of adhesion or cohesion. Kunič et al (2009) described simple mechanical tests such as cross-cut adhe$\operatorname{sion}^{23}$ to determine the mechanical stability in organic selective coatings.

However, such simple testing method cannot give a full picture to important properties like film permeability, which significantly influence the coating's durability. It is well known that properties of coating film, including ones 


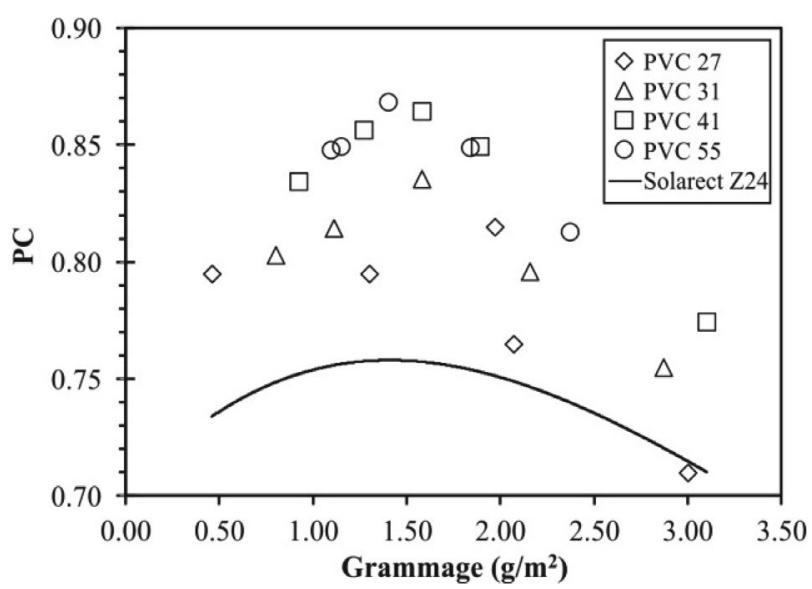

Figure 4. $\mathrm{PC}_{0,5}$ values as a function of grammage for stpTSSS at different PVC with a non-silane treated reference. Changes in PVC doesn't significantly influence the optimal grammage, which is about $1.5 \mathrm{~g} / \mathrm{m}^{2}$.

tested by cross-cut adhesion test, abruptly changes at cPVC..$^{24} \mathrm{CPVC}$ is the PVC where there is just enough binder to provide a complete adsorbed layer on the pigment surfaces and to fill the voids between pigment particles in the film. In a film with PVC > cPVC, pigment particles are not completely wetted and there are voids and/or pores between them.

To determine the cPVC of stpTSSS paints we used electrochemical impedance spectroscopy (EIS) technique. A ladder of coatings with PVCs from 25 to 55 was prepared and applied in a $20-\mu \mathrm{m}$ thickness with a bar-coater on a steel substrate. The EIS measurements of the cured coatings were performed and the results are shown as a Nyquist chart in Fig. 5.

The Nyquist chart shows that the film permeability decreases with the PVC until the cPVC is reached, after which it drops significantly. A precise determination of the PVC allowed for the development of the most selective, but still durable, coating. All subsequent experiments were performed with a coating corresponding to the coating 5 in Fig. 5.

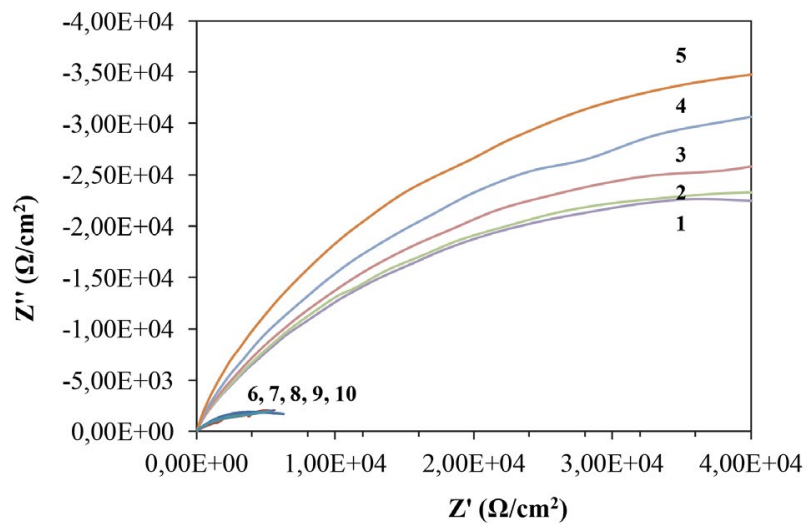

Figure 5. Nyquist chart depicting EIS measurement data as Z" versus Z' of below (1-5) and above critical (6-10) PVC stpTSSS paints.

\section{2. Spectral Selectivity}

The questions of the selectivity of the coatings and selectivity optimization were already partially addressed in the PVC dependence. Fig. 4 shows clearly that there is an optimal thickness of the coating from the point of view of selectivity. Fig. 6 shows the combined UV-VIS-NIR and IR spectra of a stpTSSS paint at different thicknesses, expressed as grammages.

The spectral data show strong pigment absorption in the UV and VIS regions, gradually diminishing in the NIR region. In the Thermal Infrared (TIR) region significant absorption bands are visible at 3-3.5 $\mu \mathrm{m}$ (C-H bond stretching), $5.8 \mu \mathrm{m}$ ( $\mathrm{C}=\mathrm{O}$ bond stretching), $7.9 \mu \mathrm{m}$ ( $\mathrm{Si}-\mathrm{C}$ bond stretching), $9 \mu \mathrm{m}$ (broad, $\mathrm{Si}-\mathrm{O}$ bond stretching), all corresponding to the paint's binder. The absorption band at $4.2 \mu \mathrm{m}$ is caused by atmospheric $\mathrm{CO}_{2}$ and is numerically subtracted in the $\mathrm{e}_{\mathrm{T}}$ calculations. The increase in the absorptivity with thickness points to well-established light-absorption and scattering phenomena as the reason for the selectivity. ${ }^{25}$ The PC data in Fig. 4, on the other hand, show a more distinct nonlinearity compared to the reference coating and point to another mechanism behind the relation between the selectivity and the thickness of the coating. We believe the explanation lies in the surface topography of a thinly applied near cPVC coating.

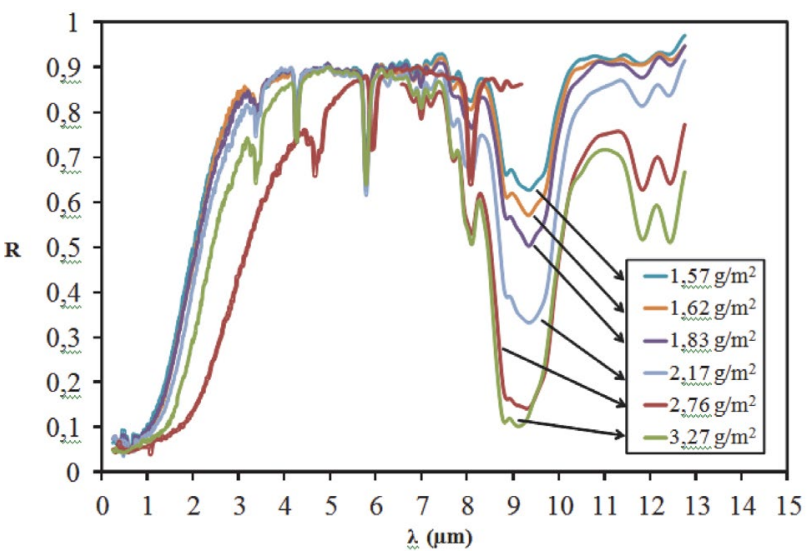

Figure 6. Combined UV-VIS-NIR and IR spectra of a stpTSSS paint applied at different grammages.

\section{3. Topography}

To interpret the topographies correctly, more data are needed, i.e., the distribution of particle sizes (PSD) in the coating. Fig. 7 shows the particle size distribution obtained by acoustic spectrometry in liquid stpTSSS paint (i.e., before application). Clearly, the bimodal distribution can be explained with pigment particles that have a median particle size of $300 \mathrm{~nm}$ and a polymer particle dispersion with a median particle size of $10 \mu \mathrm{m}$. The latter are dissolved in the curing process and not present in a cured coating. 


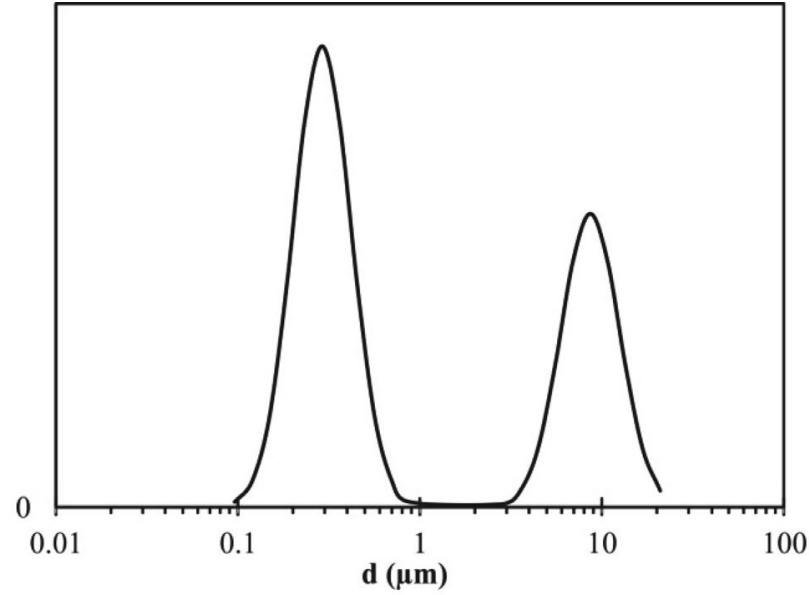

Figure 7. Particle size distribution in liquid TSSS paint.

To study the topography of the TSSS coatings applied at thickness close to the optimal one, optical microscopy is of little help, as the surface roughness of practical substrates approaches or exceeds the thickness of the coating. AFM imaging was used instead. The samples were prepared by air-spraying the paint on an aluminum substrate.

The image of the substrate in Fig. 8 shows a nano-rough surface. From the image of the stpTSSS coating with a grammage of $1.2 \mathrm{~g} / \mathrm{m}^{2}$ in Fig. 9, a nanostructure with a pattern corresponding to the particle size determined in a liquid coating superimposed on a non-flat substrate can be seen. In some spots a less structured surface due to a larger concentration of the binder can be seen. The AFM image of the surface of the stpTSSS coating with a grammage of $1.7 \mathrm{~g} / \mathrm{m}^{2}$ in Fig. 10 shows a less structured surface. The uneven surface of the substrate is better filled with the coating and the pigment particles are less obviously exposed. The trend is further evident in Fig. 11, showing an AFM image of the stpTSSS coating with a grammage of $2.4 \mathrm{~g} / \mathrm{m}^{2}$. The surface is smoother and the pigment particles are enclosed in a binder, clearly visible below the $\mathrm{CPVC}$ coating.

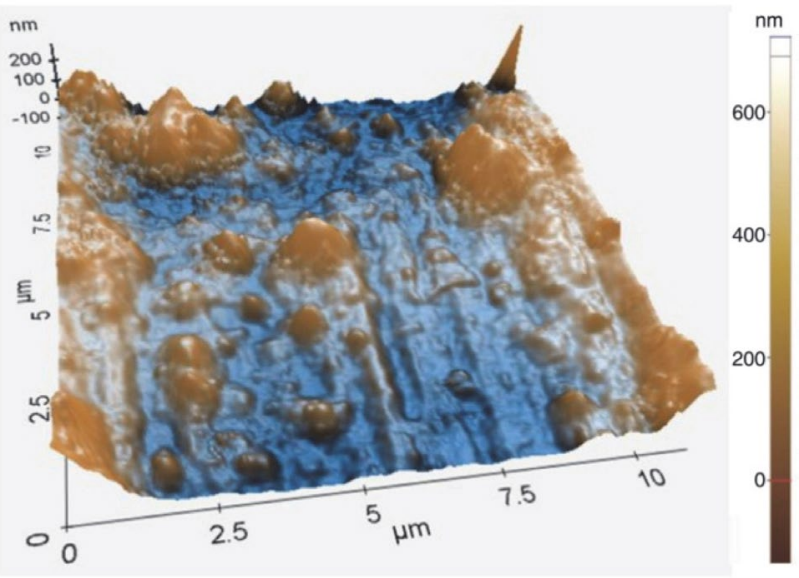

Figure 8. AFM image of aluminum substrate.

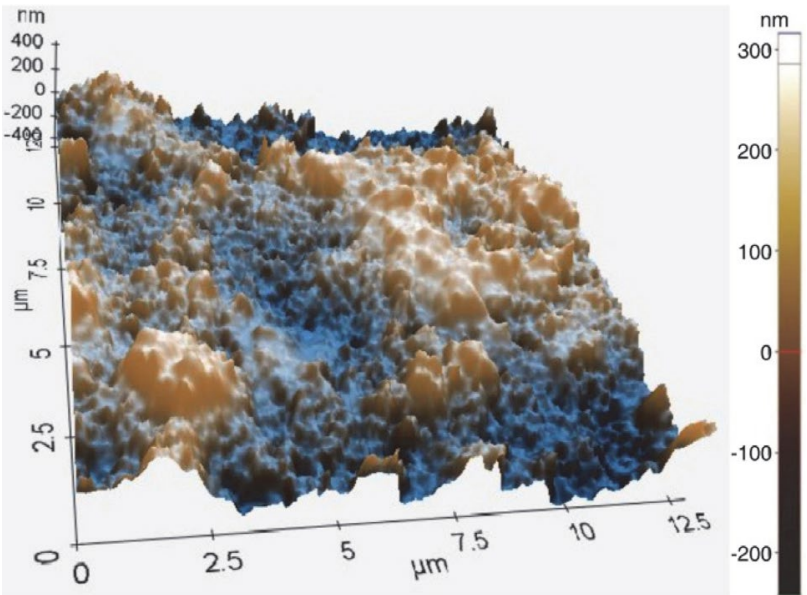

Figure 9. AFM image of stpTSSS coating with $1.2 \mathrm{~g} / \mathrm{m}^{2}$ grammage on aluminum substrate.

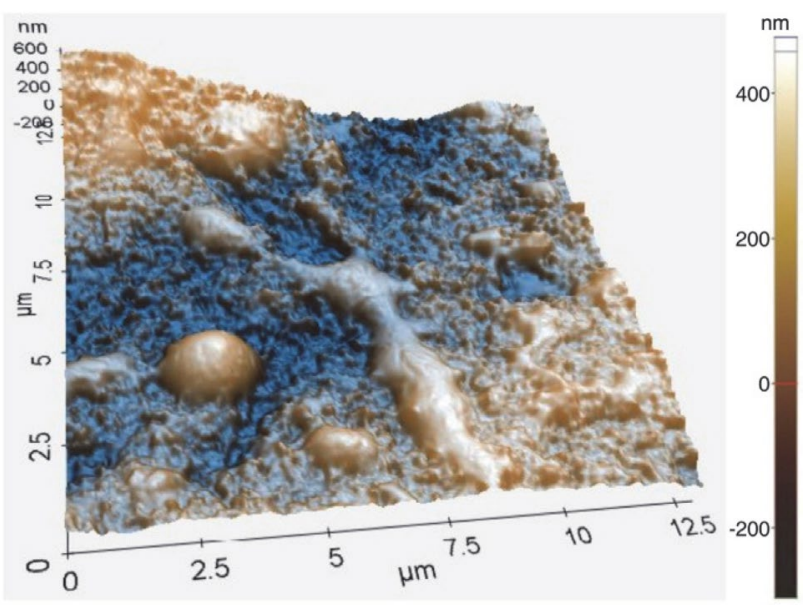

Figure 10. AFM image of stpTSSS coating with $1.7 \mathrm{~g} / \mathrm{m}^{2}$ grammage on aluminum substrate.

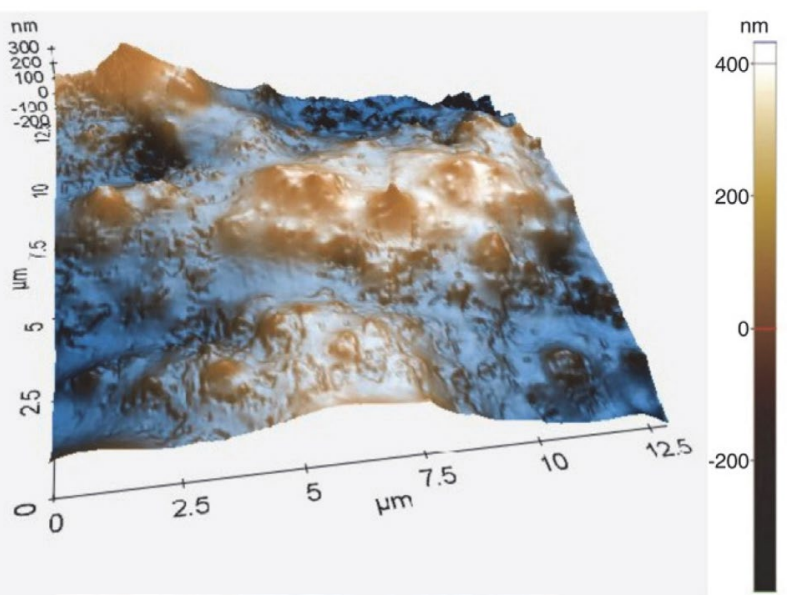

Figure 11. AFM image of stpTSSS coating with $2.4 \mathrm{~g} / \mathrm{m}^{2}$ grammage on aluminum substrate.

From the above images we can conclude that the PC versus thickness relation for the stpTSSS coatings shown in 
Fig. 4 is influenced by the change of the PVC in the top layer of the coating as a significant amount of binder is used for the substrate wetting, thus exposing more pigment particles.

\section{4. Hydrophobicity}

The nanostructure of the stpTSSS is also evident in its hydrophobicity. We present the contact angles for the water of coatings applied at different grammages in Fig. 12. As the binder has a contact angle for water of $96^{\circ}$, if applied on a thick enough layer to eliminate the influence of a substrate, it is clear from the data that the large contact angles for the stpTSSS coating are the result of structured surfaces. It could also be reasoned that the wetting of the pigment particles in the top layer of the coating is not perfect at lower grammages, resulting in lower contact angles for the more structured surfaces.

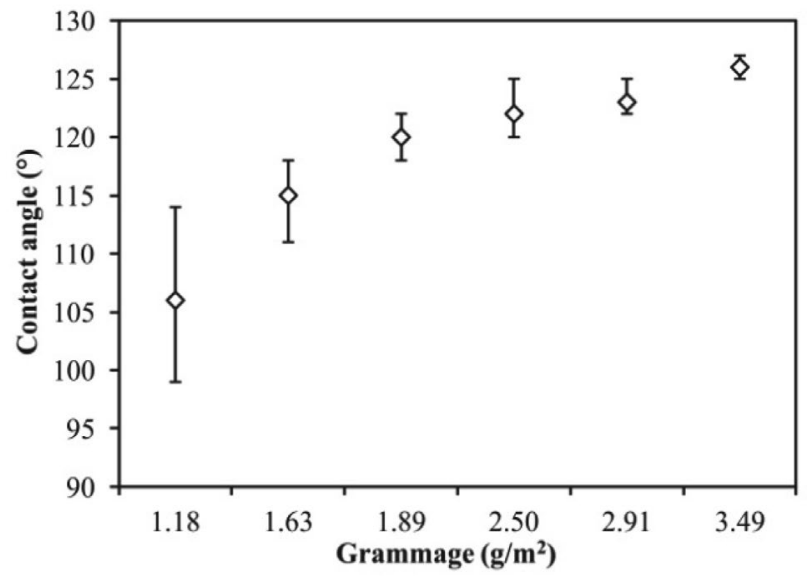

Figure 12. Contact angles for water for stpTSSS coatings applied at different grammages.

\section{5. Heat-gathering Properties}

The spectroscopic measurements (Fig. 6) and nanotopography (Figs. 8-11) must of course correspond with

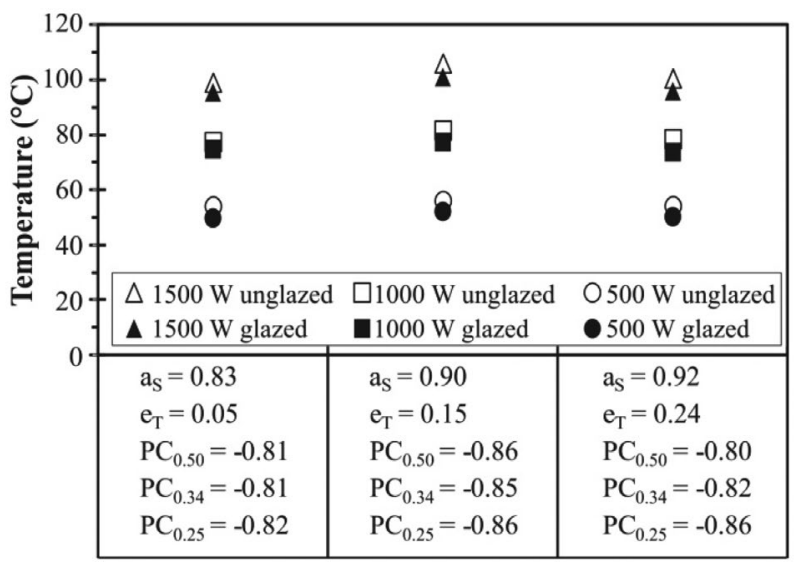

Figure 13. Stagnation temperatures and samples' spectral selectivity in heat gathering tests. practical results to be of industrial significance. To check the practicability of the stpTSSS coatings the heat-gathering properties were tested. The coatings were prepared with air spraying on an aluminum substrate. Fig. 13 shows the spectral selectivity data of the samples and the stagnation temperatures with glazed and unglazed setups at various illuminations.

The above results clearly show that the best heat-gathering properties are exhibited by the most selective sample, i.e., the one with the lowest $P C$ value. Relatively low temperatures were achieved in the setups used, which means $P C_{0.25}$ is the appropriate criteria for coating selection.

\section{Conclusions}

- Silane-treated-pigment TSSS paints (stpTSSS) produced according to a recently disclosed procedure are the first Task-X-certified ${ }^{26}$, organic, spectrally selective coatings. They have now entered industrial production on a major European producer's solar absorber surfaces coil-coating line.

- The selectivity of stpTSSS paints was studied. The performance criteria $(P C)$ of the coating were found to decrease with the pigment-volume concentration (PVC). The critical PVC (cPVC) was determined by means of EIS.

- The nonlinearity of the PC versus grammage relation was shown to be related not only to the optical properties of the pigment and the binder used, but also to the surface topography. Thin, near cPVC coatings exhibit a significantly different surface topography than the thicker coatings. We believe that sub-optimal pigment wetting by the binder in the thinly applied coatings' top layer is caused by a disproportionate amount of binder being used for the substrate wetting, resulting in a PVC gradient in the coating. This phenomenon, which is not readily observable in thicker coatings, leaves the subject open for further studies.

- Contact-angle measurements for water support the surface-topography findings, i.e., the contact angles increase with the thickness. This can be readily explained by the coatings' compositions and topographies.

- The spectroscopic measurements of the paint's selectivity correlate well with the results obtained with the stagnation temperature built up in a model collector.

\section{Acknowledgements}

Authors wish to thank the staff of Laboratory for the Spectroscopy of Materials at National Institute of Chemistry (of Slovenia) under leadership of Prof. Dr. Boris Orel for spectral selectivity measurements and the staff of Physical Analytical Laboratory at Helios d.d. under leadership 
of Dr. Saša Skale for measurements. The work was partially financed through KC-TIGR (Competence Centre sustainable and innovative construction); operation part financed by the European Union, European Regional Development Fund. MS thanks Public Agency for Technology of the Republic of Slovenia (TIA) for financing through MR-08 program, grant number P-MR-08/21; operation part financed by the European Union, European Social Fund. The authors also acknowledge the financial support from the state budged by the Slovenian Research Agency (Programme Nos. P2-0223 and P2-0392).

\section{References}

1. F. Cao, K. McEnaney, G. Chen, Z.F. Ren, Energy Environ. Sci., 2014, 7, 1615-1627. DOI:10.1039/c3ee43825b

2. ISO 9845-1, Solar energy - Reference solar spectral irradiance at the ground at different receiving conditions - Part 1: Direct normal and hemispherical solar irradiance for air mass 1,5 , ISO, Geneve, 1992.

3. SOLABS, Development of unglazed solar absorbers (resorting to coloured selective coatings on steel material) for building facades, and integration into heating systems, EU project, Contract no. ENK6- CT-2002-00679.

4. M. Koželj, B. Orel, M. Steinbücher, I. Jerman, M. Vodlan, Aminosilane-modified pigments for spectrally selective paints, methodfor their preparation and application in paints, SI Patent Number 23055, date of patent November 30, 2010.

5. M. Koželj, B. Orel, M. Steinbücher, I. Jerman, M. Vodlan, Coil-coated spectrally selective coatings on copper or aluminum with pigments modified by aminosilane, EU Patent Number 2432835 B1, date of patent January 27, 2016.

6. M. Hoeflaak, Optimization of spectrally selective coatings for flat plate solar collectors, in: $8^{\text {th }}$ International conference "Optimising paint formulation: preservation, stabilization and care", Amsterdam, Netherlands, 1988.

7. B. Orel, H. Spreizer, L. Slemenik Perše, M. Fir, A. Šurca Vuk, D. Merlini, M. Vodlan, Sol. Energy Mat. Sol. Cells, 2007, 91, 93-107. DOI:10.1016/j.solmat.2006.07.013

8. B. Orel, H. Spreizer, L. Slemenik Perše, M. Fir, A. Šurca Vuk, D. Merlini, M. Vodlan, M. Kohl, Sol. Energy Mat. Sol. Cells, 2007, 91, 108-119. DOI:10.1016/j.solmat.2006.07.012

9. E. AlShamaileh, Sol. Energ, y 2010, 84, 1637-1643.

DOI:10.1016/j.solener.2010.06.003

10. J. Manara, M. Reidinger, M. Rydzek, M. Arduini-Schuster,
Prog. Org. Coat., 2011, 70, 199-204.

DOI:10.1016/j.porgcoat.2010.09.024

11. S. Wijewardane, D.Y. Goswami, Renewable Sustainable Energy Rev., 2012, 16, 1863-1873.

DOI:10.1016/j.rser.2012.01.046

12. I. Jerman, M. Koželj, B. Orel, Sol. Energy Mat. Sol. Cells, 2010 , 94, 232-245. DOI:10.1016/j.solmat.2009.09.008

13. B. Japelj, A. Šurca Vuk, B. Orel, L. Slemenik Perše, I. Jerman, J. Kovač, Sol. Energy Mat. Sol. Cells, 2008, 92, 1149-1161.

DOI:10.1016/j.solmat.2008.04.003

14. R. Kunič, M. Koželj, B. Orel, A. Šurca Vuk, A. Vilčnik, L. Slemenik Perše, D. Merlini, S. Brunold, Sol. Energy Mat. Sol. Cells, 2009, 93, 630-640. DOI:10.1016/j.solmat.2008.12.026

15. R. Kunič, M. Mihelčič, B. Orel, L. Slemenik Perše, B. Bizjak, J. Kovač, S. Brunold, Sol. Energy Mat. Sol. Cells, 2011, 95, 29652975. DOI:10.1016/j.solmat.2011.05.014

16. ISO 2808, Paints and varnishes - Determination of film thickness, ISO, Geneve, 2007.

17. H. D. Liu, T. R. Fu, M. H. Duan, Q. Wan, C. Luo, Y. M. Chen, D. J. Fu, F. Ren, Q. Y. Li, X. D. Cheng, B. Yang, X. J. Hu, Sol. Energy Mat. Sol. Cells, 2016, 157, 108-116. DOI:10.1016/j.solmat.2016.05.035

18. Measurement of Total Solar Reflectance of Paint Panels using PerkinElmer UV/Vis/NIR Spectrophotometers and UV WinLab Software, Perkin Elmer, Inc., Waltham, USA, 2010.

19. S. Skale, V. Doleček, M. Slemnik, Corros. Sci., 2007, 49, 10451055. DOI:10.1016/j.corsci.2006.06.027

20. R. E. Lobnig, W. Villalba, K. Goll, J. Vogelsang, I. Winkels, R. Schmidt, P. Zanger, J. Soetemann, Prog. Org. Coat., 2006, 55, 363-374. DOI:10.1016/j.porgcoat.2005.11.015

21. R. E. Lobnig, V. Bonitz, K. Goll, M. Single, W. Villalba, J. Vogelsang, I. Winkels, R. Schmidt, P. Zanger, Prog. Org. Coat., 2007, 60, 1-10. DOI:10.1016/j.porgcoat.2007.03.003

22. N. Selvakumar, H. C. Barshilia, Sol. Energy Mat. Sol. Cells, 2012, 98, 1-23. DOI:10.1016/j.solmat.2011.10.028

23. ISO 2409, Paints and Varnishes - Cross-cut test, ISO, Geneve, 2007.

24. Z. W. Wicks, F. N. Jones, S. P. Pappas, D. A. Wicks, Organic Coatings: Science and Technology, $3^{\text {rd }}$ Edition, Wiley, New Jersey, USA, 2007, pp. 461-471. DOI:10.1002/047007907X

25. M. Klanjšek Gunde, J. Kozar Logar, Z. Cmjak Orel, B. Orel, Thin Solid Films, 1996, 277, 185-191.

DOI:10.1016/0040-6090(95)08023-6

26. B. Carlsson, M. Köhl, Recommended qualification test procedure for solar absorber surface durability, IEA Solar Heating and Cooling Program, Paris, France, 2005.

\section{Povzetek}

Članek obravnava od debeline odvisne spektralno selektivne premaze, ki so bili pripravljeni $\mathrm{z}$ različnimi volumskimi koncentracijami pigmenta temelječih na silansko obdelanih pigmentih. Kritična volumska koncentracija pigmenta je bila določena s pomočjo elektrokemijske impedančne spektroskopije, porazdelitev velikosti delcev pa $\mathrm{z}$ ultrazvočno spektroskopijo. Odvisnost selektivnosti od debeline premaza s skoraj kritično volumsko koncentracijo pigmenta je bila preučevana spektroskopsko na podlagi zmogljivostnega kriterija. Pokazalo se je, da je nelinearnost slednjega povezana s površinsko topografijo, kar je bilo dodatno potrjeno $\mathrm{z}$ meritvami hidrofobnosti. Meritve sposobnosti zbiranja toplote $\mathrm{v}$ simuliranem toplotnem zbiralniku so potrdile spektroskopsko določitev optimalne debeline suhega filma. 